\title{
Yüksek Doz Metilprednizolon'un HL-60 AML Hücrelerinde DNA Metilasyonu Üzerine Etkisi
}

\author{
Işıl YÜKSELEN ${ }^{l}$, Asuman SUNGUROĞLU ${ }^{2}$ \\ ${ }^{1}$ Ankara Üniversitesi Eczacllık Fakültesi Biyokimya Anabilim Dall, Ankara, Türkiye \\ ${ }^{2}$ Ankara Üniversitesi Tıp Fakültesi Tıbbi Biyoloji Anabilim Dall, Ankara, Türkiye \\ E-mail: isilyukselen@gmail.com
}

\begin{abstract}
Özet
Akut Myeloid Lösemi (AML), erken hematopoetik kök hücrelerde bir dizi genetik değişiklik sonucunda normal büyüme ve farklılaşmanın bozulması, kemik iliği ve periferik kanda çok sayıda anormal olgunlaşmamış myeloid hücrenin birikimi ile karakterize olan bir hastalıktır. Son y1llarda, löseminin oluşum sürecinde DNA metilasyonundaki ve histon modifikasyonlarındaki değişikliklerin etkili olduğu konusunda çalışmalar yapılmış ve AML ve demetile edici ajanlar hematolojik hastalıkların tedavisi için hedef olarak belirlenmiştir. Yüksek doz metilprednizolon yeni tanı almış pediatrik AML hastalarının tedavisinde kısa süreli uygulanmakta ve başarılı sonuçlar alınmaktadır. Sentetik bir glukokortikoid olan metilprednizolonun (MP) yüksek dozda, myeloid lösemi hücrelerinin granülositlere ve makrofajlara farklılaşmasını ve myeloid lösemi hücrelerde apoptozisi indüklediğine dair çalışmalar literatürde bulunmaktadır. Bizim çalışmamızda, AML hücre serisinde metilprednizolonun farklı dozlarda hücreler üzerindeki sitotoksisite düzeylerini saptamak amacıyla MTT yöntemi kullanıldı. MTT testi sonucu canlılığın anlamlı derecede azaldığı dozlarda 24. ve 48. saatlerde apoptozis ve farklılaşma analizleri akım sitometri ile yapıldı. Etken dozun 5x10-3 olarak bulundu ve bu etken dozun uygulandığ 1 HL-60 hücreleri ve kontrol grubu hücrelerinden DNA izolasyonu yapılarak metilasyon analizlerine devam edildi. AML'de sıklıkla metile olduğu bildirilen $p 15, E R$ ve anormal ekspresyonu görülen BCL-2 ve CDX2 genlerinin HL-60 AML hücre serisinde steroid tedavisi öncesi ve sonras1 metilasyonuna bakılarak, metilprednizolonun etkisini, epigenetik yolaktan gösterip göstermediğini araştırıldı. P15 geni promotoru ve BCL-2 geni promotoru metile bulunmamıştır. ER geni promotoru ve CDX2 geni promotoru ise metile bulunmuştur. MP uygulaması sonrası genlerin metilasyon profillerinde bir değişiklik saptanmamıştır. Çalışmamızda yüksek ve etken dozun hücreleri farklılaşmaya ve apoptozise götürdügü ancak bunu epigenetik yolak mekanizmalarından biri olan DNA metilasyonu üzerinden yapmadığı saptandı.
\end{abstract}

Anahtar Kelimeler: Akut Myeloid Lösemi, Metilprednizolon, Metilasyon

\begin{abstract}
Acute Myeloblastic Leukemia (AML) is a disease characterized with disruption of normal hematopoietic growth and differentiation and accumulation of numerous abnormal unmatured myeloid cells. Epigenetic mechanisms, in particular DNA methylation and histon modifications, play a major role in the modulation of gene activity in cancer and cause acute leukemias. Epigenetic changes can reverse pharmacologically with demethylating agents which are in use as targeted therapy of hematological malignancies.
\end{abstract}




\begin{abstract}
Methylprednisolone(MP) has been used with short course and high dose for treating newly diagnosed children with AML. Methylprednisolone induces differentiation of myeloid leukemia cells to granulocytes and macrophages and induces apoptosis of myleoid leukemia cells. First, MTT test is performed for evaluating how different MP doses effect cell cytotoxicity in time dependent manner. Viability decreased with increasing MP doses both 24. And 48. hours. For these doses, apoptosis and differentiation determinations were done with flow cytometry analysis. Following this step, the high and effective dose for HL60 cells established as 5x10-3. For this dose, DNA isolation wass done. After isolation, methylation specific PCR analysis was performed for p15, ER, CDX2 and Bcl-2 genes. According to results, while p15 and Bcl-2 gene promoters are unmethylated, ER and CDX2 gene promoters are methylated. In conclusion, the methylation profiles of $p 15, C D X 2, E R$ and Bcl-2 do not change after MP treatment. MP has apoptotic effect and differentiates myeloid blast cells but it does not effect DNA methylation. It is the first in the literature that demonstrates if methylprednisolone shows its effect with epigenetic pathway. In conclusion HL-60 cell line shows that MP doesn't effect DNA methylation.
\end{abstract}

Keywords: Acute Myeloid Leukemia, Methylprednisolone, Methylation

\title{
Giriş
}

Akut myeloid lösemi (AML), hematopoez sürecinde farklılaşmanın durmasıyla karakterize olan bir hematopoetik kök hücre bozukluğu olup, blast hücre populasyonunun çoğalmasıyla sonuçlanan bir hastalıktır. AML, tek bir anomaliyle oluşan bir hastalık olmayıp, birçok malignite taşıyan hematopoetik öncül hücrelerin sayısındaki anormal artış sonucu meydana gelir. Bu durum da kemik iliğinde normal hematopoezin karakteristiği olan farklılaşma ve kendini yenileme arasındaki hassas dengenin bozulmasına neden olur. Translokasyonlar gibi anormal genetik değişimlerin transkripsiyonu düzenleyen faktörlerin fonksiyonunu değiştirmesi, AML'nin bir nedeni olarak görülmektedir ve hem genetik hem de epigenetik seviyede gen programlamasını bozduğu bilinmektedir (Altucci ve ark.,2006). DNA metilasyonu sadece löseminin gelişim sürecinde değil, hastalığını gelişiminde ve tekrarlamasında da önemli etkiye sahip olmaktadır. Hücre proliferasyonu, farklılaşma ve apoptozisi düzenleyen yolaklarda çalışan birçok gen, myeloid blastlarda metilasyonla susturulmuştur ve bu genlerin transkripsiyonel olarak inaktivasyonları lösemi oluşumuyla ilişkilendirilmektedir (Blum ve Marcucci,2005). Örneğin, Ekmekçi ve ark., AML hastalarında tümör baskılayıcı genlerin metilasyonunu araştıdıkları çalışmada, 28 hastada P15 geninin metilasyonuna bakılmıştır. 18 yetişkin hastanın \% 50'sinde, 10 çocuk hastanın \% 30'unda P15 geni metile bulunmuştur (Ekmekçi ve ark.,2004). DNA metilasyonu ve posttranslasyonel histon modifikasyonları gibi DNA dizisini değiştirmeyip gen ekspresyonunu kontrol eden mekanizmalar lösemilerin tedavisinde farmakolojik olarak hedeflenmektedir.

Glukokortikoidler (dekzamethazon, metilprednizolon gibi), eklem iltihabı gibi ateşli hastalıklar, astım, dermatitis ve otoimmun hastalıkların tedavisinde çok önemli bir yere sahiptir. Dahası glukokortikoidler kanser tedavisinde de yaygın olarak kullanılmaktadır. Apoptozisi indüklemeleriyle lösemi, lenfoma ve Multiple Myeloma(MM) gibi birçok hematolojik hastalığın tedavisinde anahtar rol oynamaktadırlar (Sionov ve ark.,2008). Glukokortikoid yapıdaki Metilprednizolon 1960'ların başlarında çocukluk çağı lösemilerinde, hastalığın gerilemesini sağlamak için kullanılmaya başlanmıştır. Daha sonra glukokortikoidlerin etkili bir şekilde lenfoid hücreleri öldürdügünün bulunmasıyla, glukokortikoidler lenfoid hastalıklarda uygulanan tüm kemoterapi protokollerine katılmıştır. Çeşitli hücre serilerinde in vitro yapılan çalışmalarda, glukokortikoidlerin uzaklaştırılmasından sonra hücre döngüsünün senkronize şekilde ilerlediği gösterilmiş, buna bağlı olarak glukokortikoidlerin antiproliferatif etkisinin, hücre döngüsünün ilerleyişinde tersinir G1blokajına aracılık edebileceği bildirilmiştir (Mattern,2007). Metilprednizolon (MP) çekirdek hormon reseptör ailesine ait çinko parmak üyelerine bağlanarak işlev gören, vitamin D3 ve retinoik asiti kapsayan steroid hormon ailesinin bir üyesidir. Bu reseptör proteinleri hedef genlerin promotor bölgelerindeki spesifik DNA tanıma dizilerine bağlanır ve bu sayede transkripsiyonel değişikliğe neden olur. Metilprednizolonun da dahil olduğu steroid hormonlar, spesifik glukokortikoid 
nükleozolde yer alan reseptörlerine bağlanarak hücreler üzerindeki etkilerine göstermektedirler. $\mathrm{Bu}$ reseptörler steroidlerle birleştiğinde, spesifik DNA bölgelerine bağlanarak transkripsiyon faktörü olarak işlev görmektedirler (Uzunoglu ve ark.,1999). Metilprednizolonun, etkisini epigenetik düzeyde DNA metilasyon paterni üzerinde değişiklik yaparak gösterdiği düşünülerek bu çalışma planlanmıştır. Literatürde ilk kez MP uygulanan HL-60 hücre serilerinde p15, ER, CDX2 ve BCL-2 genlerinin promotor metilasyon profili araştırılmıştır. Yüksek doz MP uygulanan hücre serilerinde (in vitro) ilacın etkisini, p15, CDX2, BCL-2 ve ER genlerinde promotor metilasyonu üzerinde göstermediği ilk kez belirlenmiştir.

\section{Gereç ve Yöntem}

\section{HL-60 Hücre Serisinde Metilprednizolon Doz Denemeleri}

HL-60 hücreleri \%10 serum, \%1 L-glutamin, \%1 streptomisin-penisilin içeren RPMI 1640 besiyeri ortamında çoğaltıldılar. Büyümeleri için gerekli olan $37^{\circ} \mathrm{C}$ sıcaklık ve $\% 5 \mathrm{CO} 2$ içeren etüvde

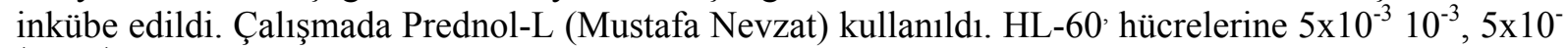
${ }^{4}, 10^{-4}$ dozlarında MP uygulaması yapıld1. Bu doz aralıklarında ve 24 . ve 48 . saatlerde sitotoksite, apoptozis ve farklılaşma için etken doz saptandı.

\section{[3-(4,5-dimethyldiazol-2-yl)-2,5 diphenyl Tetrazolium Bromid] (MTT) Sitotoksisite Testi}

Metilprednizolonun hücreler üzerindeki sitotoksisite düzeylerini saptamak amacıyla MTT yöntemi kullanıldı.

\section{Akım Sitometri İle Apoptozis Tayini}

Apoptozis tayini için, hücreler Annexin V ve propidyum iyodür ile işaretlenerek Accuri C6 cihazı ile akım sitometri analizi ile gerçekleştirildi.

\section{Akım Sitometri İle Farklılaşma Tayini}

Hücrelerin farklılaşmasını saptamak amacıyla da HL-60 hücrelerine özgü CD13, CD33 pozitifliği ve HLA-DR negatifliği ve olgun myeloid hücre yüzey antijeni olan CD11b'nin Accuri C6 cihazı ile akım sitometri analizi yapıldı.

\section{DNA İzolasyonu}

MP uygulanan ve MP uygulanmayan kontrol grubu HL-60 hücrelerinden DNA izolasyonu, Invitrogen PureLinkTM Genomic DNA Kits (Catalog nos. K1820-01, K1820-02, K1821-04) ile yapıldı. İzole edilen DNA'ların saflık derecesi ve konsantrasyonu Biotek marka Epoch model spektrofotmetre cihazı ile tayin edildi.

\section{Metilasyon Spesifik Polimeraz Zincir Reaksiyonu (MSP)}

HL-60 hücrelerinden izole edilen DNA'ların modifikasyonu CpGenomeTM DNA Modifikasyon Kiti (S7820) kullanılarak modifiye edilerek gerçekleştirildi. Modifiye edilen DNA'lardan p15, ER, CDX2 ve BCL-2 genlerine uygun primerler kullanılarak metilasyon spesifik PCR analizi gerçekleştirildi. Primer dizaynları PERLPRIMER primer dizileme programı ile kullanılarak yapıldı.

\section{İstatistiksel Analiz}

Farklı dozlarda MP uygulanan HL-60 hücrelerinin MP uygulanmayan kontrol grubuna göre 24 . ve 48. saatteki dozlara göre değişen canlılık oranları karşılaştırılarak istatistiksel olarak anlamlı bir farklılık olup olmadığı Chi-Square testi ile analiz edildi. 


\section{Sonuç}

\section{MTT Analizi}

MTT analizi sonuçlarına göre canlılık hem 24. Saate hem 48.saatte doz arttıkça azalmaktadır (Çizelge 1). MTT analizi sonuçları istatistiksel olarak değerlendirildiğinde, 24. ve 48. Saatlerde doz arttıkça canlılık anlamlı olarak azalmaktadır $(\mathrm{p}<0.001)$. Tüm dozlarda 48., saatte, 24. saate göre canlılık anlamlı olarak azalmaktadır $(\mathrm{p}<0.001)$. Canlılığın en çok azaldığg doz 48 . Saatte $5 \times 10^{-3} \mathrm{M}$ olarak belirlendi (Çizelge 2).

Çizelge 1. MTT analizine göre hücrelerin farklı dozlarda, 24. ve 48. saatlerdeki canlllk yüzdeleri

\begin{tabular}{|l|l|l|l|l|}
\hline Zaman & $\mathbf{5 x 1 0}^{-3}$ & $\mathbf{1 0}^{-3}$ & $\mathbf{5 x 1 0}^{-4}$ & $\mathbf{1 0}^{-4}$ \\
\hline 24.saat & $\% 35.2$ & $\% 69.4$ & $\% 81.7$ & $\% 80.9$ \\
\hline 48.saat & $\% 7,5$ & $\% 35.8$ & $\% 94.3$ & $\% 80.3$ \\
\hline
\end{tabular}

Çizelge 2. MP'nin saatlere ve dozlara bağımlı olarak sitotoksiteye olan etkisinin çizgi grafiği ile gösterimi

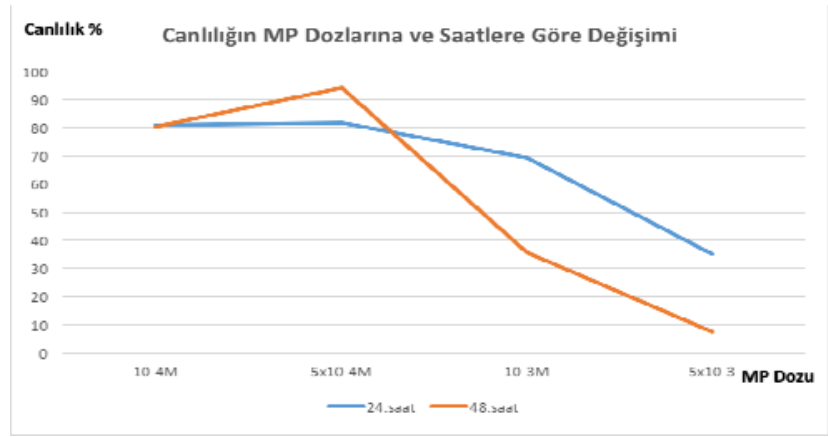

\section{Akım Sitometri İle Apoptozis Analizi}

Hücrelere uygulanan tüm dozların 24. ve 48. Saatteki apoptotik etkilerini araştırmak amacıyla her doz için örnek alınmıştır. Sonuçlara göre, yüksek doz olarak belirlenen $5 \times 10^{-3} \mathrm{M}$ doz erken apoptozis ve geç apoptozise neden olmaktadır. Uygulanan doz düştükçe geç apoptozise giren hücre sayısı da doğru orantılı olarak azalmaktadır.

Akım sitometri ile yüksek doz MP'nin literatürle uyumlu olarak apoptozis ve farklılaşmaya neden olduğu belirlendi.

A.

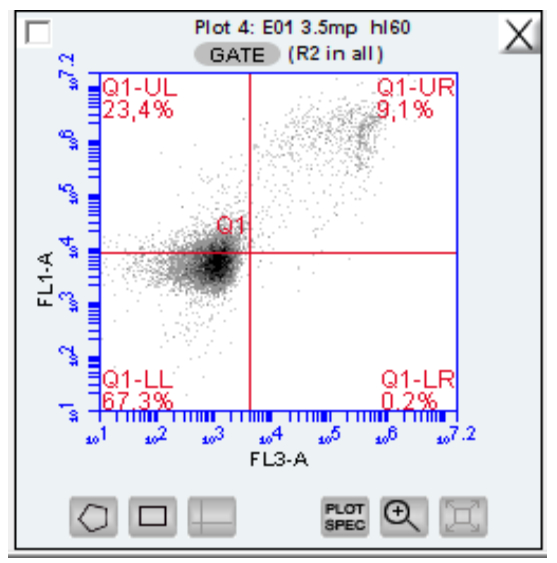

B.

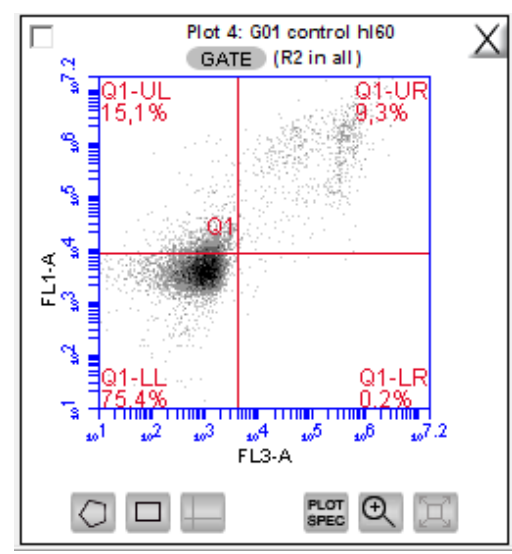

Şekil 1. A.5x10 $0^{-3}$ MP uygulanan hücre populasyonunun Anneksin V ve PI ile işaretlenmiş Hücre Populasyonunun Dağılımı. B. MP uygulanmayan kontrol hücre popülasyonu 


\section{Akım Sitometri İle Farklılaşma Analizi}

HL-60 hücrelerinin farklılaşıp farklılaşmadı̆̆ını belirlemek için CD13, CD33, HLA-DR ve CD11b antikorları ile işaretleme yapılmıştır. HL-60 hücreleri normal şartlarda CD13 ve CD33 antijenlerini eksprese etmektedir. Bu hücreler granulosit farklılaşma belirteci olan CD11b 'den yoksundurlar. Bununla birlikte, insan lökosit antijeni olan HLA-DR'yi ise eksprese etmemektedirler. HL-60 hücreleri farklılaştı̆ı̆ında CD13 ve CD33 antijen oranında azalma, CD11b oranında ise artma beklenmektedir. HLA-DR bakımından yoksun olan HL-60 hücrelerinin farklılaştıklarında bu lökosit antijenini eksprese etmeleri gerekmektedir. Bu verilere dayanarak HL-60 hücrelerinde 24. Saat ve 48. Saatlerde her dozdan örnek alınarak CD33, CD13, CD11b ve HLA-DR antikorları ile işaretleme yapıld1. 5x10-3 M olarak belirlenen yüksek dozda kontrol grubuna göre hücrelerde anlamlı bir farklılaşma saptandı. CD33 ve CD13 oranında azalma, CD11b oranında ve HLA-DR pozitifliğinde artış saptandı.

A.

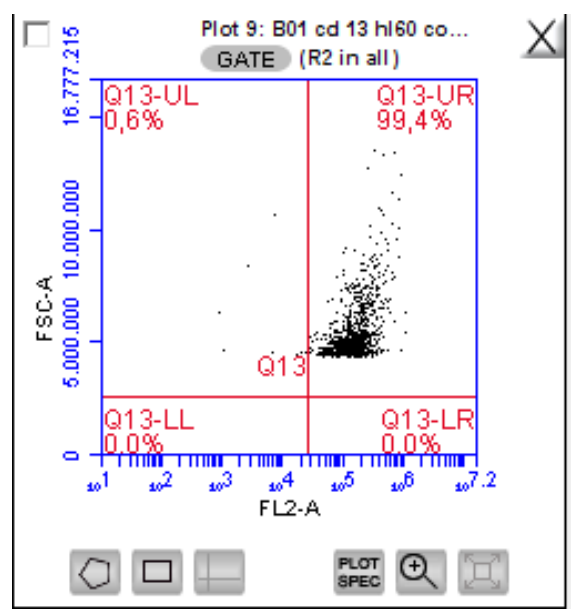

B.

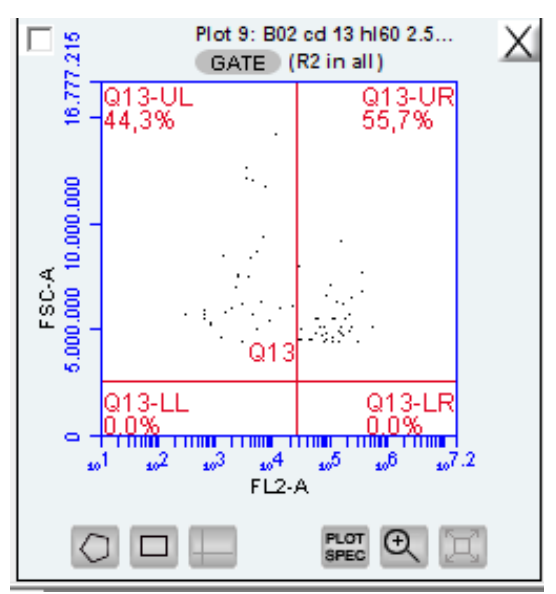

Şekil 2. Metilprednizolon uygulanan hücrelerin CD13 antikoru ile akım sitometri analiz sonuçları A. HL-60 Kontrol Grubunun CD13 antikoru ile işaretlendiği populasyon. B. 5x10-3 M MP uygulanan HL-60 hücrelerinin CD13 antikoru ile işaretlendiği populasyon

A.

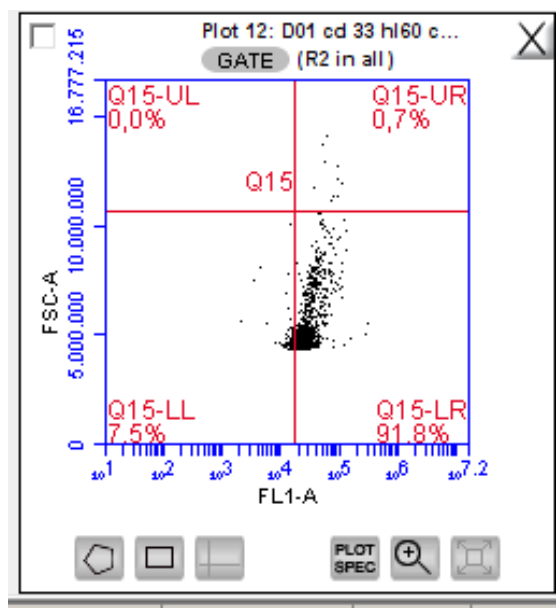

B.

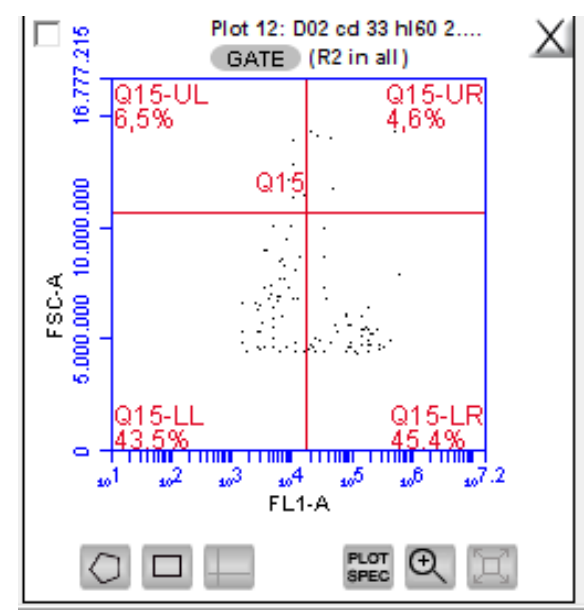

Şekil 3. Metilprednizolon uygulanan hücrelerin CD33 antikoru ile akım sitometri analiz sonuçları A. HL-60 Kontrol Grubunun CD33 antikoru ile işaretlendiği populasyon. B. 5x10 $0^{-3}$ M MP uygulanan HL-60 hücrelerinin CD33 antikoru ile işaretlendiği populasyon 
A.

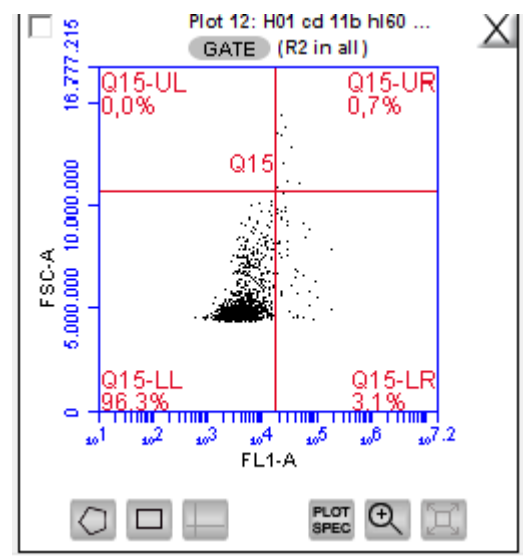

B.

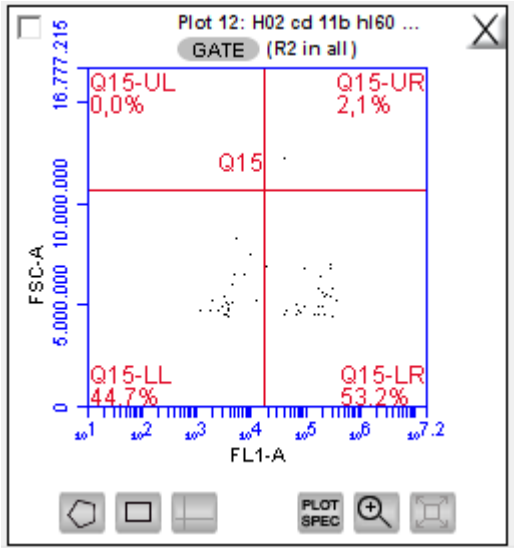

Şekil 4. Metilprednizolon uygulanan hücrelerin CD11b antikoru ile akım sitometri analiz sonuçları A. HL-60 Kontrol Grubunun CD1 lb antikoru ile işaretlendiği populasyon. B. 5x10-3 M MP uygulanan HL-60 hücrelerinin CD11b antikoru ile işaretlendiği populasyon

A.

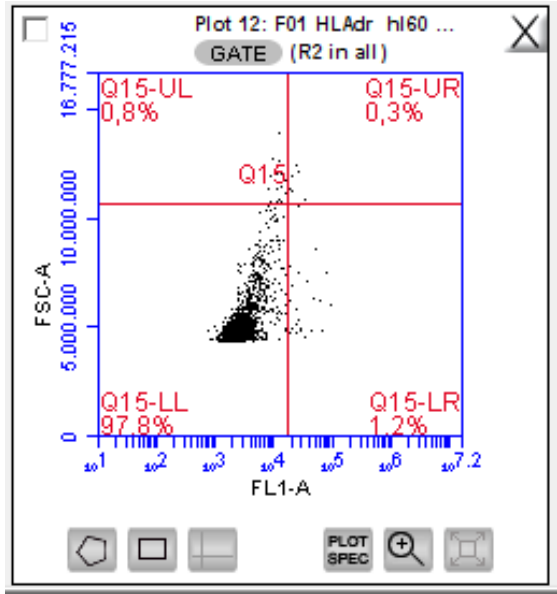

B.

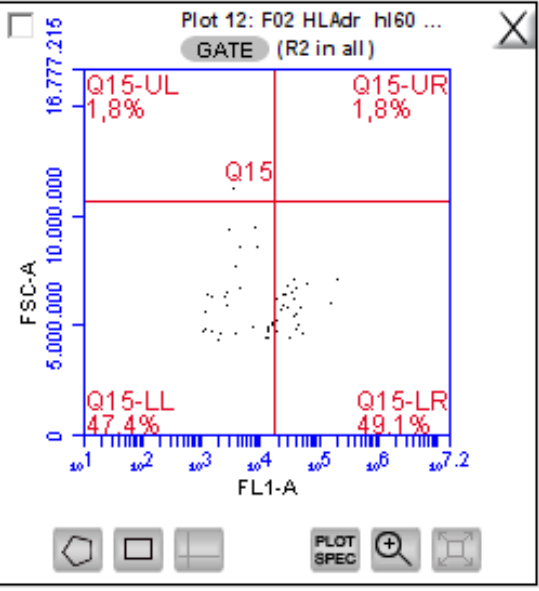

Şekil 5. Metilprednizolon uygulanan hücrelerin HLA-DR antikoru ile akım sitometri analiz sonuçları A. HL-60 Kontrol Grubunun(MP uygulanmayan) HLA-DR antikoru ile işaretlendiği populasyon. B. $5 \times 10^{-3}$ M MP uygulanan $H L-60$ hücrelerinin HLA-DR antikoru ile işaretlendiği populasyon

Apoptozis ve farklılaşma için de etken $\operatorname{doz} 5 \times 10^{-3} \mathrm{M}$ olarak belirlendi. 48. saatte, 24.saate göre daha yüksek oranda apoptozis ve farklılaşma saptand1. Farklılaşma analizinde etken dozda, kontrol grubuna göre HL-60 yüzey antijenleri olan CD13, CD33 antikorlarında azalma saptanırken farklılaşma belirteci CD11b antikorunda artış saptanmıştır.

\section{Metilasyon Spesifik PCR Sonuçları}

Kontrol grubu hücrelerinin ve etken doz $5 \times 10^{-3} \mathrm{M}$ MP uygulanan hücrelerin DNA'ları bisülfit ile muamele edildikten sonra yapılan MSPCR sonucunda, HL-60 hücrelerinin kontrol grubunda ER ve CDX2 genleri metileyken, p15 ve BCL-2 genlerinin metile olmadığı saptand. MP uygulanan hücrelerde de aynı şekilde ER ve CDX2 genleri metileyken, p15, ve BCL-2 genlerinin metile olmadığ1 saptand1 (Şekil 6). 


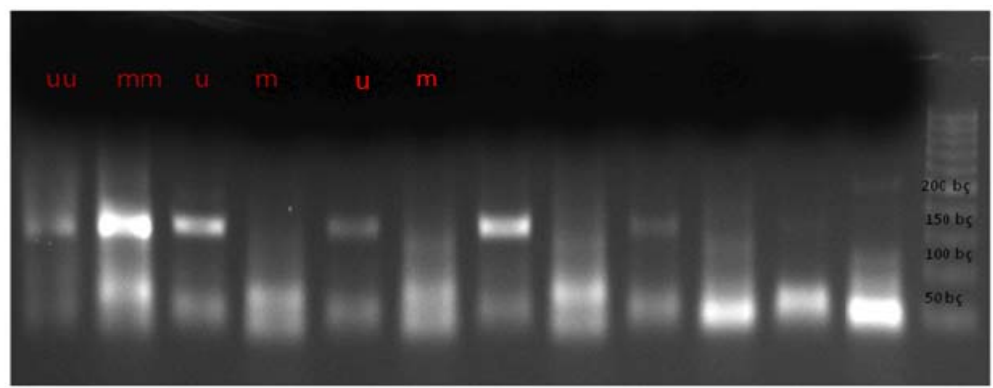

Şekil 6. MSPCR sonucu elde edilen ürünlerinin \%2'lik jelde görüntülenmesi

\section{TARTIŞMA}

DNA metilasyonu sadece löseminin gelişim sürecinde değil, hastalığını gelişiminde ve tekrarlamasında da önemli etkiye sahip olmaktadır. DNA metilasyonu ve posttranslasyonel histon modifikasyonları gibi DNA dizisini değiştirmeyip gen ekspresyonunu kontrol eden mekanizmalar lösemilerin tedavisinde farmakolojik olarak hedeflenmektedir. DNA metiltransferaz veya histon deasetilaz inhibitörleri gibi ilaçlar bu mekanizmaları değiştirerek normal gen fonksiyonunu tekrar yerine getirmektedir (Blum ve Marcucci,2005). 1970'lerin başından beri, Prednizolon (PRD) ve Dekzamethazon (Dex) üzerine yapılan birçok deneysel çalışma sonucunda, fare myeloid hücrelerini makrofaj ve granülositlere farklılaştıran en etkili ajanların Prednizolon ve Dekzamethazon olduğu bulunmuştur. Metilprednizolonun (MP) farklılaşmayı ve/veya apoptozisi indükleyici etkisini araştırmak amaciyla insan primer AML hücreleri ve HL-60, NB4, U-937 gibi myeloid lösemi hücre hatları üzerinde in vitro olarak da doz-bağımlı çalışmalar yapılmıştır. Uzunoğlu ve ark., HL-60 hücre serisine MP uyguladıkları çalışmada, toksik olmayan ve farklılaşmaya neden olan dozu $10^{-4} \mathrm{M}$ olarak saptamışlardır (Uzunoğlu ve ark.,1999). Bizim çalışmamızda bu dozdan farklı olarak yüksek doz olarak belirlenen $5 \times 10^{-3} \mathrm{M}$ dozda farklılaşma saptanmıştır. $10^{-4} \mathrm{M}$ dozda farklılaşma görülmemektedir. Bizim çalışmamızda 48.saatte $5 \times 10^{-3} \mathrm{M}$ dozda hücrelerin apoptoza gittiği ve farklılaştıkları saptandı. $\mathrm{Bu}$ sonuç, yüksek doz MP'nin apoptoza ve farklılaşmaya götürdüğü bilgisini doğruladı. Metilprednizolonun etkisini, epigenetik yolaklardan biri olan DNA metilasyonu üzerinden gösterip göstermediğini araştırmak amacıyla, metilasyonun saptanmasında kullanılan metilasyon spesifik PCR yöntemi uyguland. Bu amaçla apoptozis ve farklılaşma için anlamlı doz olan $5 \times 10^{-3} \mathrm{M}$ uygulanan hücrelerden DNA izolasyonu yapıldıktan sonra, bisülfit modifikasyonu gerçekleştirildi. Modifiye edilen DNA'lar ile P15, CDX2, ER ve BCL-2 genlerinin metilasyon spesifik pcr'lar1 yapıldı. MP uygulanmayan kontrol grubu HL-60 hücrelerinde P15 geni promotoru ve BCL-2 geni promotoru literatürde yapılan çalışmalarla tutarlı olarak metile bulunmamıştır (Paul et al.,2010, Wang et al., 2011). ER geni promotoru ve CDX2 geni promotoru literatürde yapılan çalışmalarla tutarlı olarak metile bulunmuştur (Yao et al., 2009, Scholl et al., 2007). MP uygulanan hücrelerde kontrol grubuna göre metilasyon profilinde bir farklılık saptanmadı. Bu çalışma ile literatürde ilk kez MP uygulanan HL-60 hücre serilerinde p15, ER, CDX2 ve BCL-2 genlerinin promotor metilasyon profili araştırılmıştır.

Çalışmamızda yüksek doz MP uygulanan HL-60 AML hücre serilerinde, MTT ve akım sitometri analizleri sonucu ilacın canlılığ anlamlı derecede azalttığı saptandı. Akım sitometri ile yüksek doz MP'nin literatürle uyumlu olarak apoptozis ve farklılaşmaya neden olduğu belirlendi. HL-60 myeloid blastik hücrelerde diferansiyasyon için in vitro etkin MP dozu, yapılan çalışma sonrası hastalara uygulanan doz ile uyumlu olarak 5x10-3 M olarak belirlendi. Yüksek doz MP uygulanan hücrelerde(in vitro) ilacin etkisini, p15, CDX2, BCL-2 ve ER genlerinde promotor metilasyonu üzerinde göstermediği ilk kez belirlendi. 


\section{Referanslar}

ALTUCCI L., CLARKE N., NEBBIOSO A., SCOGNAMIGLIO A., GRONEMEYER H. (2005). Acute myeloid leukemia: Therapeutic Impact Of Epigenetic Drugs. European Journal of Cancer. 37; 1752-1762.

BLUM W., MARCUCCI G. (2005). Targeting Epigenetic Changes in Acute Myeloid Leukemia. Clinical Advances in Hematology\&Oncology. 3; 855- 882.

EKMEKCI G., GUTIE'RREZ M.I., SIRAJ A.K., OZBEK U., HATIA K. (2004). Aberrant Methylation of Multiple Tumor Supressor Genes in Acute Myeloid Leukemia. American Journal of Hematology. 77; 233240.

MATTERN J., BÜCHLER MARKUS W., HERR I. (2007). Cell Cycle Arrest by Glucocorticoids May Protect Normal Tissue and Solid Tumors from Cancer Therapy, Cancer Biology \& Therapy. 6; 1345-1354.

PAUL T.A., BIES J., SMALL D., WOLFF L. (2010). Signatures of polycomb repression and reduced H3K4 trimethylation are associated with p15INK4b DNA methylation in AML. Blood. 115; 3098-3108.

SCHOLL C., BANSAL D., DOHNER K., EIWEN K., HUNTLY B. J.P., BENJAMIN H. LEE, RUCKER F.G., RICHARD F. SCHLENK, LARS B., HARTMUT D., D. GARY G., STEFAN F. (2007). The homeobox gene CDX2 is aberrantly expressed in most cases of acute myeloid leukemia and promotes leukemogenesis. The Journal of Clinical Investigation. 117;1037-1048.

SIONOV R. V., SPOKOINI R., SHLOMIT K. E., COHEN O., YEFENOF E. (2008). Mechanisms Regulating the Susceptibility of Hematopoietic Malignancies to Glucocorticoid Induced Apoptosis. Advanced Cancer. $101 ; 127-248$.

UZUNOGLU S., USLU R. , TOBU M. , SAYDAM G., TERZİGLU E., BUYUKKECECİ F., OMAY S.B. (1999). Augmentation of ethylprednisolone-induced differentiation of myeloid leukemia cells by serine:threonine protein phosphatase inhibitors. Leukemia Research. 23;507-512.

WANG J., LI L.,YU X.,JIA J., CHEN C. (2010). CIP2A is over-expressed in acute myeloid leukaemiaand associated with HL60 cells proliferation and differentiation. INTERNATIONAL JOURNAL OF LABORATORY HEMATOLOG. 33; 290-298.

YAO J., HUANG Q., ZHANG XIAO-BING, FU WEI-LING. (2009). Promoter CpG methylation of estrogen receptors in leukemia. Biosciece Reports. 29; 211-216. 